\title{
Secondary School Students' Assessment of Innovative Teaching Strategies in Enhancing Achievement in Physics and Mathematics
}

\author{
Agommuoh, Patience Chinyere. (Ph.D) ${ }^{1}$, Dr. Ifeanacho, Angela.O. ${ }^{2}$ \\ Department of Science Education, College of Agricultural and Science Education, Michael Okpara University \\ of Agriculture, P. M. B. 7267, Umudike, Umuahia, Abia State, Nigeria.
}

\begin{abstract}
The study employed a descriptive survey to investigate senior secondary school students' assessment of innovative teaching strategies in enhancing achievement in physics and mathematics. By the use of purposive sampling 190 out of a population of 394 senior secondary school year one physics and mathematics students from two co-educational senior secondary schools in Umuahia North LGA of Umuahia Education Zone of Abia State was used. The instrument for data collection was the researchers developed structured questionnaire of the Likert type on senior secondary school students' assessment of innovative teaching strategies in enhancing achievement in physics and mathematics. Two (2) research questions and one (1) hypothesis tested at 0.05 level of significance guided the study. The instrument was validated and the reliability index of 0.86 was obtained. The research questions were answered using mean while the hypothesis was tested with chi-square statistics. Results showed that inquiry method, discovery learning, discussion, role play, simulation, games, team teaching, brainstorming and other similar strategies were agreed to be innovative teaching strategies that can enhance achievement in physics and mathematics. A recommendation that physics and mathematics teachers should be encouraged to use these innovative teaching strategies in the teaching of physics and mathematics was made.
\end{abstract}

Keywords: Innovation, Teaching Strategies, Science, Mathematics and Physics

\section{Introduction}

Science is a dynamic human activity which is concerned with the working of the world. It is the bedrock on which modern day technological breakthrough is built. This is why developing countries like Nigeria are working hard to develop scientifically and technologically since the world is a scientific and technological global village where all proper functioning of lives largely depends on science. Science according to Ting-Kueh (2006) plays major roles in creating new knowledge, economic development and wealth creation. This assures social wellbeing by eradicating poverty and providing better health care which improves the quality of human living in several ways. Science finds its application in all facets of life such as agriculture, medicine, energy and power supply, biotechnology, space research and nuclear technology. This means that the understanding of science helps man to know more about the universe and things around us. Nigeria as a nation appreciates the importance of science in its quest to transform its economy successfully. This can be seen in the mission statement of the new National Policy on Science, Technology and Innovation (FRN, 2012), which seeks to evolve a nation that develops and utilizes science, technology and innovation to build a large, strong, diversified sustainable and competitive economy that will guarantee a high standard of living and quality of life for all its citizens. Without the application of science, it will be very difficult for man to live and adjust in a fast scientifically developing world.

Science comprises the basic discipline such as Physics, Chemistry, Mathematics and Biology. Physics which is one of the core sciences is crucial to understand the world around us, the world inside and the world beyond us. It is the most basic and fundamental science. Physics challenges our imagination with concepts like relativity and strong theory which leads to great discoveries and technologies that change our lives. Its importance cannot but over emphasized hence the need for all citizens to study the subject with utmost understanding.

Mathematics which is a science that draws necessary conclusions also provides special skills required by an individual to solve his day to day problems, communicate effectively, reasons appropriately and makes necessary connections (Harbour - Peter 2000; Obodo, 2000; Kolanole and Oluwata 2005; Borasi, 2008). The British National curriculum (2004) asserted that mathematics equips pupils with uniquely powerful tools to understand and change the world. The importance of mathematics can be seen in its applications to science and technology, medicine, the economy, the environment and in public decision making. The implication is that for effective functioning in the society, there is need for all the citizens to study and understand science and mathematics.

In spite of the importance and usefulness of physics and mathematics, secondary school students' achievement in the subjects is very discouraging. Researchers have shown that secondary school students 
exhibit dwindling interest in the subjects (Esiobu, 2005). Studies have also revealed that the performance of mathematics in ordinary level physics and mathematics was generally and consistently poor in the years (Agwagah, 2005)

Poor academic achievement in physics and mathematics could be attributed to many factors among which are the teachers' teaching strategies. This means that physics and mathematics concepts cannot be well understood if students are not taught with effective teaching strategies. Many researchers have blamed this poor achievement in physics and mathematics on the use of inappropriate teaching strategies which might lead to lack of interest and retention of physics and mathematical concepts (Agommuoh, 2004; Agwagah, 2005; Harbor Peters, 2000; Ifeanacho, 2012; Iji and Harbour-Peters, 2005; Kurumeh, 2004; and Ogbonna 2007).

Current studies on how students learn science and mathematics revealed new and innovative instructional approaches in the teaching of science and mathematics (Agommuoh, 2010; Ifeanacho, 2012; and Ogbonna, 2007). Science and especially physics and mathematics teaching have undergone a paradigm shift from a passive process to an active construction and interpretation of experiences. Screeden and Sudler (2011) explained that learning is a treasure within, and scientific knowledge is being actively built up and constructed by the learners. This is the constructivist view of learning science and mathematics. The constructivists see learning as an interaction between the learner and his environment. During this interaction between the learner and his environment his prior knowledge becomes the basis for him to interpret and construct new knowledge. The implication is that learning is a process in which the learners invent and develops new ideas. This means that learning physics and mathematics is a process of conceptual change and knowledge navigation. Learning in this case involves the restructuring of student conceptions. Teachers must learn to appreciate the ideas students bring into the learning situation, understand the processes by which the conceptual change occurs in order to design the learning programmes. Learning is learner centered which makes the learner an active participant in the learning environment. New learning in this case depends on the learners' previous knowledge that may at times interfere with the understanding of the new information.

The teaching and learning of physics and mathematics must aim at achieving the aims and approaches of physics and mathematics education which are as follows;

- Development of process skills like observation, classification, communication, measurement, estimation and prediction.

- Acquisition and understanding of knowledge development of the skills for problem solving and investigations.

- Ability to think logically as well as to draw conclusion on the basis of experiment.

- Development of the ability to reach generalization and to apply them for solving life problems.

- Development of understanding of inter-relationship of science and mathematics.

- Fostering creativity for innovations in science and mathematics.

The minds of the young need to be exposed to critical thinking, analysis and problem solving strategies in a fast-changing world like ours. The teaching and learning of science especially mathematics and physics requires a unified and comprehensive approach relying on teachers that are professionally trained and equipped with requisite knowledge and skills. The adoption of student-centered instructional strategies which includes the inquiry method, discussion, role play, simulation, games and other similar strategies have been shown to enhance the active participation of students in the teaching and learning of physics and mathematics. According to Screeden and Sudler (2011) some other approaches for effective physics and mathematics teaching includes;

1. Orientation - Here the teacher introduce the topic.

2. Elicitation of ideas which involves opportunities provided for the students to explore and explain their ideas.

3. Classification and Exchange where students are given a chance to realize scientific and mathematical ideas in examining their own ideas.

4. Exposures to conflict situation which involves students being provided with situation which will enable them test their ideas and recognize the limitation of these ideas.

5. Constructions of new ideas- students are provided with opportunities to restructure (extend, modify or replay their ideas.

6. Evaluation involves students being provided with opportunities to test the validity of their newly construct ideas.

7. Applications of ideas - students are provided opportunities to apply their idea in new situations to reinforce the ideas.

8. Review change in ideas which involves students being given opportunity to refer upon how and why their ideas have changed.

Effective teaching according to Obi (2003) is a process related to the teachers' consciousness of the individuality of each child, including his needs, strengths, weaknesses, growth patterns and background of experiences. This means that an effective teacher has to create an atmosphere for a wholesome teaching and 
learning. Stressing further on this Anyachebelu (2005) explained that effective teaching as a situation whereby the teacher is vast in attainment, knowledge and skills as well as possession of certain pre- requisites and acceptable practices within the codes of ethics of teaching profession. Obi (2003) identified five components of effective teaching to include:

1. Knowledge of subject matter

2. Ability to help students with their works

3. Presenting subject matter appropriately

4. Motivating students to excel and

5. Firmness/fairness in preparing marking guides and grades of examination.

For effective and successful physics and mathematics teaching, teachers must understand how students think and construct scientific and mathematical knowledge. The implication is that physics and mathematics teachers need to teach these subjects effectively for a successful preparation of today's individuals for tomorrow (Zakaria \& Iksan, 2007). The teacher must know how students learn these subjects and how best to teach them. Physics and mathematics teaching is not for knowledge depositing and information thrusting but should inculcate scientific temper and values. For effective teaching, the learner is provided with opportunities to have an optimal learning experience through constructing his own knowledge. The teacher must provide a democratic climate in the classroom for effective teaching and learning of physics and mathematics. This democratic climate creates a conducive environment for the students to enable them freely state their point of view. This encourages active participation of the students in the classroom. The focus is for the teacher to use learner centered innovative pedagogical strategies in the teaching and learning of the subjects. Such innovative strategies include peer tutoring, simulation, team teaching, brainstorming, cognitive apprenticeship, discovery learning, inquiry and role play strategies. The secondary school physics and mathematics curriculum is designed to provide students with knowledge and skills that will enable them solve problems and make decision in everyday life (Ministry of Education Malaysia, 2002). Students need knowledge, problem-solving skills, creative and critical thinking for proper adjustment into a fast scientifically and technologically developing society like ours. Students must therefore be taught to meet up with the challenges ahead and demand by daily living. This is very imperative since lecture based instruction which is teacher centered has been identified as a major shortcoming in the teaching and learning of physics and mathematics (Madu, 2004). This is because according to Kurumah (2004), lecture method emphasizes passive acquisition of knowledge by students who do not have conceptual understanding but memorize the learning content. Bearing in mind the nature of physics and mathematics, there is therefore, the need for the teacher to use innovative teaching strategies in the teaching of the subjects so as to enable the students learn and acquire positive attitudes and values, process skills and problem-solving skills. Hence the need for the study.

\section{Purpose of the Study:}

The purpose of this study is to investigate senior secondary school students' assessment of these innovative teaching strategies in enhancing achievement in physics and mathematics.

\section{Research Questions}

The following research questions guided the study.

1. What are senior secondary school students' assessment of innovative teaching strategies in enhancing achievement in physics and mathematics?

2. What are male and female senior secondary school students' assessment of innovative teaching strategies in enhancing achievement in physics and mathematics?

\section{Hypothesis}

The hypothesis below tested at $\mathrm{P}<0.05$ significant level guided the study

1. There is no significant difference in the scores of male and female senior secondary school students' assessment of innovative teaching strategies in enhancing achievement in physics and mathematics.

\section{Methodology}

The study adopted a descriptive survey. By the use of purposive sampling one hundred and ninety (190), 98 males and 92 females out of a population of three hundred and ninety four (394) senior secondary school year one physics and mathematics students from two (2) co-educational senior secondary schools in Umuahia North LGA of Umuahia Education zone of Abia State was sampled. The instrument used for data collection was the researchers developed structured questionnaire of the Likert type on senior secondary school students' assessment of innovative teaching strategies in enhancing achievement in physics and mathematics. The responses were Strongly Agree (SA), Agree (A), Disagree (D) and Strongly Disagree (SD) weighted 4, 3, 2,1 respectively. It is a ten-item questionnaire that is made up of innovative teaching strategies that can be used 
in the teaching of physics and mathematics. The instrument was face and content validated by three experts in the physics and mathematics education of the Department of Science Education of the Michael Okpara University of Agriculture, Umudike Umuahia Abia State, Nigeria. The reliability index was determined by cronback alpha and found to be 0.86 . The questionnaires were distributed by the researcher and collected back and so the percentage return was $100 \%$. Two (2) research questions and one (1) hypothesis tested at 0.05 level of significance guided the study. The research questions were answered using means, while the hypothesis was tested using chi-square statistics.

\section{Results}

The results in respect of mean scores of students' assessment of innovative teaching strategies in enhancing achievement in physics and mathematics used in answering research questions 1 and 2 are shown in tables 1 and 2 below.

Table 1:

Mean scores of senior secondary school students' assessment of innovative teaching strategies in enhancing achievement in physics and mathematics.

$\begin{array}{clcccccc}\text { S/N } & \text { ITEM } & \text { SA } & \text { A } & \text { D } & \text { SD } & \text { X } & \text { REMARKS } \\ \text { 1. } & \text { Peer Tutoring } & 80 & 60 & 35 & 15 & 3.08 & \text { Agree } \\ \text { 2. } & \text { Simulation } & 85 & 66 & 25 & 14 & 3.17 & \text { Agree } \\ \text { 3. } & \text { Team Teaching } & 88 & 68 & 23 & 11 & 3.23 & \text { Agree } \\ \text { 4. } & \text { Brainstorming } & 90 & 70 & 20 & 10 & 3.26 & \text { Agree } \\ \text { 5. } & \text { Experiential Learning } & 85 & 65 & 25 & 15 & 3.16 & \text { Agree } \\ \text { 6. } & \text { Cooperative Learning } & 84 & 64 & 30 & 12 & 3.16 & \text { Agree } \\ \text { 7. } & \text { Cognitive apprenticeship } & 85 & 72 & 20 & 13 & 3.21 & \text { Agree } \\ \text { 8. } & \text { Discovery Learning } & 86 & 67 & 23 & 14 & 3.18 & \text { Agree } \\ \text { 9. } & \text { Inquiring Learning } & 88 & 70 & 21 & 11 & 3.24 & \text { Agree } \\ \text { 10. } & \text { Role Play } & 68 & 90 & 20 & 12 & 3.13 & \text { Agree }\end{array}$

Table 1 above clearly showed that all the items have mean values greater than 2.5 which is the mean value of the four point scale used in the study meaning that all the students agreed that these items are innovative teaching strategies that can enhance achievement in physics and mathematics.

Table 2:

Mean scores of male and female senior secondary school students' assessment of innovative teaching strategies in enhancing achievement in physics and mathematics.

$\mathbf{S} / \mathbf{N}$

\section{ITEM}

1. Peer Tutoring

2. Simulation

3. Team Teaching

4. Brainstorming

5. Experiential Learning

6. Cooperative Learning

7. Cognitive apprenticeship

8. Discovery Learning

9. Inquiring Learning

10. Role Play

\section{MALE \\ Mean (X)}

3.30

3.21

3.35

3.30

3.42

3.06

3.17

3.42

3.26

3.36
REMARKS

FEMALE
Mean (X)

2.85

Agree

Agree

Agree

Agree

Agree

Agree

Agree

Agree

Agree

Agree

\section{REMARKS}

Agree

Agree

Agree

Agree

Agree

Agree

Agree

Agree

Agree

Agree

Result in table 2 shows that all the items have mean values greater than 2.5 meaning that all the students both males and females agreed that the ten items listed above are innovative teaching strategies that can enhance achievement in physics and mathematics.

The results in respect of $x^{2}$ values of male and female secondary school students' assessment of innovative teaching strategies that can enhance achievement in physics and mathematics used in answering the hypothesis is shown in table 3 below. 
Table 3:

$\chi^{2}$ values of male and female secondary school students' assessment of innovative teaching strategies that can enhance achievement in physics and mathematics.

$\begin{array}{llcclll} & & \text { SA } & \text { A } & \text { D } & \text { SD } & \text { TOTAL } \\ \text { MALE } & \mathbf{9 8} & 451 & 393 & 99 & 37 & \mathbf{9 8 0} \\ & & (432.7) & (356.9) & (124.8) & (65.5) & \\ \text { FEMALE } & 92 & 388 & 299 & 143 & 90 & \mathbf{9 2 0} \\ & & (406.3) & (355.1) & (117.2) & (61.5) & \\ & \mathbf{8 3 9} & \mathbf{6 9 2} & \mathbf{2 4 2} & \mathbf{1 2 7} & \mathbf{1 9 0 0}\end{array}$

$x^{2} \mathrm{cal}=50.6, x^{2}$ crit $/ \mathrm{tab}=7.815, \mathrm{df}=3$.

Table 3 above clearly showed that $x^{2}$ calculated value of 50.6 is greater than the $x^{2}$ critical/ table value of 7.815. The null hypothesis of no significant difference was rejected and the alternate hypothesis accepted. This therefore means that there is a significant difference in the mean scores of male and female secondary school students' assessment of innovative teaching strategies that will enhance achievement in physics and mathematics.

\section{Discussion}

Tables 1 and 2 showed that all the items have mean values greater than 2.5 which means that all the students both males and females agreed that peer tutoring, simulation, team teaching, brainstorming, experiential learning, cooperative learning, cognitive apprenticeship, discovery learning, inquiring learning and role play are innovative teaching strategies that will enhance their achievement in physics and mathematics. This result is in agreement with Akinbobola (2008) who opined that new approach of communicating science and mathematics is by involving students and making sure that they participate fully rather than listening to talks and taking notes. Science teaching has been shifted from the teacher centered approaches to student centered approaches of learning such as inquiring and problem - solving methods (Akinbobola, 2008).

This result also agrees with Akinbobola and Ado (2007) who explained that these innovative strategies which include brainstorming, peer tutoring and role play help the learner to acquire appropriate skills, abilities and competences as equipment for the individual to solve life problems and contribute to the development and growth of the society. According to Bransford, Brown and Cocking (2000) the major goal of teaching is to prepare students to be able to adopt knowledge to various problems and setting and using multiple context. This can only be achieved by using innovative teaching strategies that will involved students full participation in the teaching and learning environment. Effective teaching of physics and mathematics puts a great emphasis on students' participation in the learning process which implies that students have to be active rather than simply passive recipients of information from the teacher, textbook or any other source of information involved in the learning contexts. Active participation and involvement of the students in the learning situation can only be through the use of a wide range of innovative teaching and learning strategies such as peer tutoring, simulation, team teaching, brainstorming, experiential learning, cooperative learning, cognitive apprenticeship, discovery learning, inquiring learning and role play.

\section{Conclusion}

The job of the teacher requires that he assists the learner to learn. The teacher can do this by effectively by making the teaching environment stimulating, challenging and dynamic. The aim of teaching is not only to transmit information but also to transform passive students into active receptors of knowledge and constructor of their own knowledge. The use of innovative teaching and learning strategies in educational institutions has the potential to improve achievement, empower students and galvanize the effort to achieve the human development goals for the country.

\section{Recommendation}

For the enhancement of achievement in physics and mathematics through effective teaching and learning, the following recommendations are made;

1. Innovative teaching strategies such as team teaching, brainstorming, peer tutoring etc should be reflected in physics and mathematics teacher education curriculum to enable new graduate teachers be fully equipped for teaching and learning of the subjects.

2. Conferences, workshops, and seminars should be organized for the practicing and serving science and mathematics teachers to update their knowledge/ skills in the application of these strategies which will enhance quality teaching and learning of the subjects. 
3. Science and mathematics students should be encouraged to be actively involved in the learning environment by engaging in these innovative teaching and learning strategies.

\section{References}

[1]. S. Ting - kueh, "Future of our civilization: Benefits and Perils of Advanced Science and Technology". In Vladimir, B (ed). The future of life and the future of our civilization. Netherlands: Springer, 2007.

[2]. Federal Republic of Nigeria, Science, Technology and Innovation Policy. Abuja: Federal Ministry of Science and Technology, 2012.

[3]. V. F. Harbour- Peters, Andragogical Inquiry. A pedagogical Model for teaching mathematics within the next millennium.. ABACUS: The Journal of Mathematics Association of Nigeria 2000, 25 (1) 64 - 72.

[4]. G. C. Obodo, "Mathematics a language for computers in the new millennium. Implication for Nigeria". Proceeding of Annual conference of Mathematics Association of Nigeria, 2000.

[5]. E. B. Kolawole, \& J. A. Oluwatayo, Mathematics for Everyday Living. Implications for Nigerian Secondary Schools ABACUS, $2005,30(1), 51-57$.

[6]. Borasi, How and what mathematics is taught: Retrieved (16-4-2008) from http://www.pdkintl.org/kappan/kbat/9902.htm

[7]. British National Curriculum Targets as it relates to mathematics. http://www.courtfields.somerset.sch.uk/maths/resource.htm ,2004.

[8]. G. O. Esiobu, Gender issues in science and technology education for development in Ivowi U. M. O. (ed.) Science and Technology Education for Development, Lagos, Adecos Education Science Ltd. , 2005.

[9]. U. N. V. Agwagah,. Teaching mathematics for critical thinking, essential skill for effective living. ABACUS, 2005, 30 (1), 38-45.

[10]. P. C. Agommuoh, Effects of videotaped instruction on secondary school students' physics. An unpublished MED thesis, University of Nigeria, Nsukka, 2004.

[11]. A. O. Ifeanacho, Effect of Kumon teaching strategy on junior secondary school students' achievement, interest and retention in statistics. An Unpublished Ph.D thesis, University of Nigeria, Nsukka, 2012.

[12]. C. O. Iji, \& V. F. Harbour - Peters Effects of logo and basic programs on the achievement in geometry of junior secondary school students. ABACUS, 2005, 30 (1) 28 - 40. Mathematics Education Series.

[13]. M. S. Kurumeh, Effects of ethno mathematics approach in teaching on students' achievement and interest in geometry and menstruation. Unpublished Ph.D Thesis, University of Nigeria, Nsukka, 2004.

[14]. C. C. Ogbonna, A comparative study of the effectiveness of two constructivist instructional models on students' academic achievement and retention in JSS mathematics. An Unpublished Ph.D Thesis, University of Nigeria Nsukka, 2007.

[15]. P. C. Agommuoh, Effects of prior knowledge, exploration, discovery, dissatisfaction with prior knowledge (PEDDA) and the learning cycle (TLC) constructivist instructional models on students' conceptual change and retention in physics. An unpublished Ph.D thesis, University of Nigeria, Nsukka, 2010.

[16]. P. S. Screeden, \& M. A. Sudhir, Innovative strategies for science teaching: International Journal of Educational Science and Research, 2011, 1 (1), $1-10$.

[17]. E. Anyachebelu, Educational Psychology. Effective methods for improving teaching and learning. Lagos: Paprus Publishers, 2005.

[18]. E. Obi, Educational Management: Theory and Practice. Awka: Jamoc. Enterprise, 2003.

[19]. E. Zakaria, \& Z. Iksan, Promoting cooperative learning in science and mathematics education. A Malaysian Perspective. Eurasia Journal of Mathematics, Science and Technology Education, 2007,3 (1) $35-39$.

[20]. Ministry of Education, Malaysia, Integrated curriculum for secondary schools. Curriculum specification for scienceform 1 . Curriculum Development Centre, Ministry of Education, 2002.

[21]. B. C. Madu, Effects of constructivist - based instructional model on students' conceptual change and retention in physics. An Unpublished Ph.D Thesis, University of Nigeria, Nsukka, 2004.

[22]. A. O. Akinbobola, Facilitating Nigerian physics students' attitude towards the concept of heat energy. Scientia Padaegogica Experimentalis, 2008, 45. 353-366.

[23]. A. O. Akinbobola, \& I. B. Ado, Hands- on and minds - on strategies for teaching of force: Guided discovery approach In: Udo, E.; Uyoata, U.; Inyang, N. E. U.; Yero, H.; \& Bello, G. (eds). Hands- on and minds - on in the teaching of force. Uyo Afahaide \& Bros Printing 2007.

[24]. J. D. Bransfor; A. L. Brown; \& R. R. Cocking, How people learn: Brain, mind, experience and school. Washington D. C. National Academy Press, 2002. 